\title{
Exílio na Cidade: Algumas Reflexões ${ }^{1}$
}

\author{
Silvia Maia Bracco ${ }^{2}$
}

Resumo:

$\mathrm{O}$ artigo aborda questões que incluem fenômenos inconscientes presentes na cultura e atravessam os sujeitos vítimas da humilhação e desamparo social. Reflete sobre a contribuição que o psicanalista pode oferecer para estabelecer novas formas de compreensão dos fenômenos que nos cercam, ampliando a relação da psicanálise com as questões do mundo, seus limites e sobretudo sua potência. Pretende explorar esse tema, apoiado em uma situação ligada ao processo de reurbanização e realocação de populações que vivem em favelas na vizinhança do CEAGESP.

Discute a lógica da exclusão e preconceito vigente, trabalhando com a ideia de invisibilidade, o terror da dessubjetivação e a angústia diante do estranho. O referencial teórico centrou-se nas ideias de Arendt, Gonçalves Filho e Debieux.

\footnotetext{
${ }^{1}$ Resumo de trabalho apresentado na mesa "O psicanalista e a saúde coletiva " no eixo "Psicanálise e suas clinicas" com Rosana Onocko Campos no I Simpósio Bienal "O mesmo, o outro: Psicanálise em movimento" da Sociedade Brasileira de Psicanálise de São Paulo.

${ }^{2}$ Membro da SBPSP, Mestre em Psicologia Clínica - PUC/SP, Coordenadora da área de Saúde do Ateliê Acaia e do setor de Parcerias e Convênios da DAC-SBPSP.
} 